\title{
Medievalista
}

Online

$28 \mid 2020$

Número 28

la participación eclesiástica castellana

\section{Diplomacia y construcción monárquica}

la participación eclesiástica castellana

Diplomacy and the building of monarchy: the participation of ecclesiastics in Castile

\section{Óscar Villarroel González}

\section{OpenEdition}

Journals

Edición electrónica

URL: http://journals.openedition.org/medievalista/3313

DOI: $10.4000 /$ medievalista.3313

ISSN: $1646-740 \mathrm{X}$

Editor

Instituto de Estudos Medievais - FCSH-UNL

\section{Edición impresa}

Paginación: 191-223

Referencia electrónica

Óscar Villarroel González, «Diplomacia y construcción monárquica», Medievalista [En línea], 28 | 2020, Publicado el 01 julio 2020, consultado el 23 marzo 2021. URL: http://journals.openedition.org/ medievalista/3313 ; DOI: https://doi.org/10.4000/medievalista.3313

Este documento fue generado automáticamente el 23 marzo 2021.

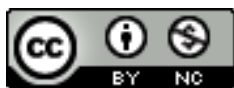

Mediavalista está licenciado com uma Licença Creative Commons - Atribuição-NãoComercial 4.0 Internacional. 


\section{Diplomacia y construcción monárquica}

la participación eclesiástica castellana

Diplomacy and the building of monarchy: the participation of ecclesiastics in Castile

Óscar Villarroel González

\section{Introducción}

1 La participación de eclesiásticos en la diplomacia no supone ninguna novedad para la historiografía actual. Son múltiples los casos de análisis en los que, desde un punto de vista u otro (el análisis de la monarquía, de la diplomacia, de los conflictos...), se ha podido constatar la presencia de eclesiásticos en funciones diplomáticas. Esto es extensible para la historiografía de la Corona de Castilla y yo mismo, en alguna ocasión anterior, he participado en ese análisis ${ }^{1}$. No vamos aquí a descubrir nuevos mediterráneos, ni a transitar rutas ya conocidas. El objetivo de este trabajo es profundizar en una vía que está apenas esbozada: el funcionamiento de la diplomacia castellana y la participación eclesiástica en su evolución.

2 Hoy día empezamos a comprender cómo funcionaba la diplomacia en el periodo medieval: los usos, formas, documentos, la organización institucional... No importa ya tanto (aunque también) conocer todas las embajadas y su evolución, sino que se pone el foco de atención en cómo funcionaba todo el sistema y sus aparatos ${ }^{2}$. Esto es prácticamente común a la mayor parte de los reinos occidentales, aunque el caso castellano supone una excepción, puede que parcial. Como se sabe, la falta de documentación es la fuente del problema, al no conservarse apenas documentación diplomática castellana ${ }^{3}$. Sólo ahora estamos siquiera empezando a caminar en un mejor análisis y comprensión de su organización y funcionamiento. Todo ello por dos vías: por un lado, gracias al análisis, según nuevos puntos de vista, de la documentación 
existente y ya conocida; y en segundo lugar de las nuevas fuentes que van apareciendo con el rastreo de archivos extranjeros a Castilla.

3 Y ahora lo que se plantea, aunque sea de forma tímida y apenas tanteando el terreno, es analizar si hubo eclesiásticos que participasen de una forma u otra en la organización o mejora de los aparatos diplomáticos de la monarquía. Es decir, si ayudaron a construir la monarquía por medio de la diplomacia, y especialmente por medio de la organización de las tareas diplomáticas. Esta participación en la génesis del Estado, que se ha analizado de forma exhaustiva de forma general en los diversos poderes occidentales, no se ha tratado de forma específica en lo que toca a la organización de la diplomacia. Sí su participación en ella, como se ha dicho, pero no la impronta que pudieron dejar en la misma.

4 Esta participación en la construcción paulatina de la diplomacia castellana y sus formas organizativas pudo llevarse a cabo de diversas formas:

- Organización de misiones concretas de una forma específica y que luego perdurase en el tiempo.

- Colaboración en la organización de una base institucional para la dipomacia en la corte castellana, es decir, en su vertiente más burocrática.

5 Ciertamente, cualquiera de los dos caminos es complicado por la falta de fuentes. Sin embargo, sí podemos encontrar algunos jalones y retazos de noticias que nos muestran a eclesiásticos realizando tareas específicas en ese sentido. Por un lado, podemos atender a cómo participaron en los diversos niveles burocráticos de la diplomacia. Tanto en el interior de la propia organización institucional, como en los puestos más representativos de la misma (los que participaban en embajadas). De esta forma, podemos llegar a vislumbrar tanto la propia organización interna, como el papel de los eclesiásticos en ella.

6 Por otro lado, nos encontramos también con el desarrollo de lo que podríamos denominar auténticas misiones ejemplares, que nos sirven para observar el funcionamiento de la diplomacia (y del servicio de estos eclesiásticos). Las que así denominamos pueden serlo por dos vías distintas. o bien porque encontramos que algunos eclesiásticos desarrollaron su misión con tal capacidad que suponen claros ejemplos a imitar en otras posteriores, o bien porque tenemos conjuntos documentales excepcionales de esas misiones que nos permiten un mejor conocimiento de las mismas. Sea como fuere, en ambos casos nos permiten vislumbrar por un lado una vertiente representativa o simbólica: la preocupación por mostrar y defender una imagen determinada de la monarquía castellana. Por otro lado, merced a esa documentación excepcional, podemos atender a la vertiente organizativa (cómo se preparaban las cuestiones, qué documentación se utilizaba, quién la gestionaba y cómo, la división de los roles a jugar...).

7 A estas dos vías de aproximación dedicaremos el presente trabajo. Por un lado, tantearemos si es posible detectar la presencia de eclesiásticos en la formación de la burocracia en el entorno de la diplomacia (si es que esta existió: no se ha visto o apreciado hasta ahora nada parecido, salvo los análisis ingleses ${ }^{4}$, si acaso la especial relación que en los archivos tiene, en ocasiones, la documentación diplomática5). Por otro, veremos cómo cuando participaban en las embajadas también podían suponer un ejemplo organizativo. Con ello se pretende ilustrar cómo los eclesiásticos participaban también en la construcción de un importante aparato regio como era la diplomacia, así como alguno de sus principales aportes en el caso castellano. 


\section{La participación de eclesiásticos en el desarrollo de la diplomacia}

8 Como se ha comentado ya, la participación de eclesiásticos en la diplomacia en Castilla es un hecho ya conocido y analizado, aunque sea de forma general en ocasiones, o demasiado concreta en otros ${ }^{6}$. Gracias a ello sabemos que estamos en un punto realmente inicial de la aproximación a su conocimiento. La falta de fuentes no permite, de momento, un análisis exhaustivo. Lo que conocemos, sin lugar a dudas, no es más que una parte muy superficial de lo que esperamos conocer en los próximos años ${ }^{7}$. Pese a ello, podemos esbozar la forma en la que estos eclesiásticos participaron en el desarrollo del aparato diplomático monárquico.

¿Es viable este tipo de análisis? No podemos negar que puede resultar complicado por la falta de fuentes. Y que esto tiene como consecuencia que cualquier resultado que se extraiga en estos estadios iniciales de la investigación serán siempre inestables y provisionales, al albur siempre de que nuevos hallazgos documentales o incluso reinterpretaciones y relecturas de los ya conservados, sirvan para modificar (en parte o en todo) lo ya indicado. Pese a ello, a día de hoy existen menciones y documentación que permiten hilvanar una evolución (aunque sea muy superficial y a grandes rasgos) de la presencia de eclesiásticos en la organización burocrática y con ello de su participación en el funcionamiento del sistema.

\section{La presencia en la organización burocrática}

Interesa especialmente el desarrollo que pudieron tener los eclesiásticos en este tipo de papeles, fundamentales para el buen funcionamiento de la diplomacia. Es obvio que participaron como embajadores, y también con otros roles entre los enviados (como veremos), pero lo cierto es que también en la propia corte podemos rastrear otro tipo de actuaciones. Dentro del personal al servicio regio en ocasiones nos encontramos con funciones específicas que tenían un especial significado para la diplomacia y, sobre todo, una especial funcionalidad. Obviamente no era, en muchas ocasiones, algo único e incompatible. Es conocido cómo desde mediados del XIII se fue desarrollando la administración regia en diversos aparatos con funciones específicas: las cámaras de cuentas, los tribunales de justicia y los órganos de asesoramiento político fueron apareciendo de forma casi simultánea en todo el occidente, y Castilla no fue una excepción. La aparición y/o evolución de la fiscalidad regia ${ }^{8}$, de la Cancillería Real ${ }^{9}$, de la Audiencia Rea ${ }^{10} \mathrm{o}$ del Consejo Real ${ }^{11}$ han sido tratadas tanto desde el punto de vista institucional como en su papel en la génesis del Estado Moderno. En todo ello, además, había una cierta tendencia a la burocratización, con personal dedicado a esas instituciones de forma específica y especializada ${ }^{12}$. En algunos casos, ocurría que dentro de alguno de estos organismos había algunos oficios que tenían especial relación con la diplomacia, o que llevaban a cabo tareas de especial peso para la diplomacia.

11 La cuestión que se nos plantea es si, dentro de ese cada vez más abundante personal, encontramos algunos con un peso específico en el servicio diplomático o, al menos, con dedicación a estas tareas. Ciertamente desde el siglo XV empezamos a encontrar 
algunos de sus nombres, así como las funciones que llevaron a cabo, especialmente en algunas áreas.

Así, por ejemplo, cabe destacar la secretaría de latín. La existencia de esta secretaría, que podemos documentar desde la década de los años treinta del siglo $\mathrm{XV}^{13}$, tenía, en el caso castellano una especial importancia para la comunicación diplomática. En la Corona de Castilla convivían diversas lenguas romances (gallego, leonés, castellano) y una lengua no romance (la lengua vascona evolucionando hacia los dialectos actuales del euskera). Eso la asemejaba a otros ámbitos peninsulares donde ocurría lo mismo (la Corona de Aragón, por ejemplo, con el aragonés, catalán y siciliano). Sin embargo, había una diferencia fundamental con todos ellos: la lengua oficial de la monarquía. De forma efectiva desde el siglo XIII (y con antecedentes en el reinado de Alfonso VIII) la lengua que utilizaba la monarquía en todas sus facetas administrativas del reino era el castellano. Esto la diferenciaba de la cancillería aragonesa, donde además de utilizar las diversas lenguas romances de la Corona el latín actuaba como lengua de la administración ${ }^{14}$. Es por ello que en Castilla la utilización de la lengua latina en la cancillería y el resto de las instituciones regias tenga una especial característica. Efectivamente, el latín era utilizado para algunas comunicaciones con la Iglesia (siempre hacia el exterior y no de forma exclusiva), y para cuestiones diplomáticas y relaciones exteriores del reino. No era la única, ciertamente, pues sabemos que también había especialistas en árabe en la corte castellana, aunque no conozcamos mucho ni de su funcionamiento orgánico ni de la producción documental que emanaba de ellos (pues no se conserva) ${ }^{15}$.

13 Uno de los primeros jalones de su existencia lo encontramos en 1312, cuando en las Cortes de Valladolid se establece la figura del escribano de latín y su salario ${ }^{16} \cdot ¿^{\text {Data de }}$ ese momento la primera presencia de tal cargo? De momento es la primera noticia que tenemos.

14 Anteriormente sí nos encontramos, obviamente, escribanos regios que dominan el latín y que redactan documentos regios en esta lengua, pero no tienen ningún cargo especial. Así, por ejemplo, durante el reinado de Alfonso X, cuyo entorno cancilleresco conocemos bastante bien gracias al trabajo de Marina Kleine, nos encontramos con escribanos que escriben de forma recurrente en latín, aunque no de forma exclusiva: Diego Ibáñez, por ejemplo, aparece redactando en diversas ocasiones documentación diplomática, pero no era su único cometido, aunque es relevante que tienen ese objetivo 6 de los 10 documentos que recopiló Kleine, es decir un $60 \%{ }^{17}$; otro ejemplo, Sancho Pérez, que actuó en tres cartas del infante Alfonso, hijo de Alfonso X, dirigidas a Jaime I (aunque sólo el protocolo y escatocolo estaban en castellano), suponiendo un $100 \%$ de sus actuaciones al servicio del infante, pero solo un 3,7\% dentro de las 82 actuaciones al servicio de la monarquía ${ }^{18}$; o Juan Pérez de León, que escribió en latín dos cartas con destino diplomático, de entre 15 que se tienen documentadas (un $13,3 \%)^{19}$. No deja de ser curioso, eso sí, que cuando escribían en latín siempre era con destino diplomático.

Sea como fuere, desde principios del XIV encontramos, pues, al menos a personal destinado específicamente para la documentación en latín. Eso continuaría a lo largo del siglo, aunque conocemos muy poco al respecto y solo menciones aisladas. Así, en 1352 aparece mencionado Gutier Gómez, que era chantre de Santiago de Compostela, como notario mayor de latín ${ }^{20}$. No es baladí, además, el hecho de que aparezca como tal en una carta de nombramiento de embajadores para negociar la paz con el rey Pedro IV 
de Aragón. Sin lugar a dudas es un salto cualitativo el pasar de la existencia de escribanos de latín a la de un notario mayor de latín, puesto que nos hablaría, sin duda, de una mayor organización institucional bajo el notario, con escribanos a su servicio.

Durante el resto del reinado de Pedro I esa estructura administrativa seguía existiendo, y el cargo también era ejercido por un eclesiástico. Al menos así se puede afirmar en 1364 cuando era notario mayor de latín Fernán González de Castro, arcediano de Alcaraz y vicario en el arzobispado de Toledo por el primado Gómez Manrique ${ }^{21}$. Un dato de interés nos aporta este nuevo notario mayor: su vinculación con el arzobispado de Toledo, algo que se repitió en los decenios siguientes.

Las siguientes noticias, sin embargo, nos llevan a principios del siglo XV y damos un paso atrás en cuanto a la organización institucional. En este caso nos encontramos con la mención del cargo específico de escribano en latín. La primera mención hallada a la presencia de este puesto lo encontramos en 1407. Se trata en concreto de Pedro Fernández de la Guardia. En la carta que se dirigió al reino el 15 de enero de 1407 con los acuerdos para la gobernación del reino de Catalina de Lancáster y el infante Fernando, aparece el dicho Fernández de la Guardia entre los testigos, con la titulación "escrivano de latín"22. No deja de ser curiosa esa posición, teniendo en cuenta que unos años antes era secretario del rey Enrique III y embajador en Inglaterra ${ }^{23}$, así como sus importantes funciones diplomáticas posteriores ${ }^{24}$, y que ese mismo año de 1407 vuelve a aparecer como secretario, esta vez de Juan $\mathrm{II}^{25}$. Una carrera al servicio regio que compaginó con su condición eclesiástica: canónigo de Burgos, arcediano de grado, arcediano de Madrid .... ${ }^{26}$.

De esta forma, aparentemente nos encontramos con una reducción o destrucción de un aparato más consolidado (con un notario mayor de latín), que tras la primera guerra civil castellana pasa a tener solo escribanos de latín (al menos aparentemente pues no hay menciones a notarios mayores). Sin embargo, desde este punto se avanzaría hacia una organización centrada en torno a un personaje específico para el trabajo en latín: el secretario de latín. Con ello nos encontraríamos con que se produce el mismo cambio que, en general, se introduce en la forma de trabajo de la monarquía con la llegada de la dinastía tratámara dentro de la dinámica de cambios administrativos. Al tiempo que el sistema de los secretarios empieza a imponerse ${ }^{27}$, como personajes trabajando en estrecha colaboración con el rey. Es digno de reseña que los secretarios tuvieron notables funciones diplomáticas también (fruto, sin duda, de esa estrecha colaboración con el monarca). El mejor ejemplo de ese cambio sería el ya mencionado Pedro Fernández de la Guardia: secretario, embajador y también escribano de latín. En él se unen ambas facetas: secretario y especialista en latín. El paso a dar, pues, era breve.

La existencia del secretario de latín la tenemos documentada ya desde 1429, cuando ejerce tal función Gonzalo González Capoche ${ }^{28}$. Después de él conocemos, antes de mediados de siglo, otros tres secretarios de latín: Luis González de Llanos en $1433^{29}$, Martín de Ávila en $1449^{30}$ y entorno a esa fecha, pero con seguridad en 1452 a Juan de Mena $^{31}$. Es decir, empezamos a encontrar una continuidad en la existencia del puesto. Lo relevante, además de su propia existencia, es que de nuevo encontramos una especial vinculación entre estos personajes y la diplomacia. Así, Gonzalo González Capoche, por ejemplo, participó en las negociaciones de Ágreda-Tarazona de 1430-1433 $3^{32}$ y Luis González de Llanos estuvo en el Concilio de Basilea ${ }^{33}$.

20 Martín de Ávila y Juan de Mena, sin embargo, suponen cambios relevantes. En primer lugar forman parte del entorno cultural de la corte (aunque también lo sean del 
burocrático), y en segundo lugar, algo achacable al final solo al primero, no era clérigo. Así, Martín de Ávila, del entorno del marqués de Santillana y luego de Alonso Carrillo ${ }^{34}$, además de secretario de latín y luego cronista, también realizó diversas traducciones del latín, alguna por orden del marqués de Santillana ${ }^{35}$. Juan de Mena, por su parte, fue también cronista y secretario de latín, como se ha dicho. Este insigne poeta no parece que participase en la diplomacia, aunque sí sabemos que estuvo en Italia. Primero se supuso que estuvo en Roma y se decía que en la comitiva del cardenal Cervantes, pero no hay datos al respecto ${ }^{36} ; \mathrm{y}$ más tarde se supo que había estado en Florencia en la comitiva, como familiar continuo comensal, del cardenal Juan de Torquemada al menos hasta $1443^{37}$. Noticia relevante, sabemos además de que era clérigo (pero sólo de tonsura, y que sobre los años 50 dejó tal condición al contraer matrimonio), que tenía algún beneficio y que aspiraba a algún otro ${ }^{38}$.

Hay otro elemento en común entre algunos de estos secretarios de latín: su paso del servicio a los arzobispos de Toledo al del rey. Esto ocurre en el caso de Gonzalo González Capoche y en el de Martín de Ávila. No es extraño que el servidor de un grande del reino acabase sirviendo al monarca, por la misma colaboración del noble o eclesiástico con el rey, y no fue la primera ni la última ocasión en que ocurrió, pero no deja de ser digno de reseña también esa coincidencia.

De esta forma, podemos ver cómo en la organización de la secretaría de latín, que consideramos especialmente vinculada a la diplomacia, tuvieron un cierto peso escribanos, notarios y luego secretarios que tenían condición eclesiástica. Una condición que unieron a su participación en actos diplomáticos (embajadas, negociaciones...) y que sin duda fueron una base para su participación en ese nuevo puesto que estaba desarrollándose en la corte.

\section{Presencia en embajadas: embajadores y otros servidores}

Es obvio que, además de en el aparato burocrático, los eclesiásticos también desempeñaron importantes funciones incardinados dentro de alguna embajada. De esta forma tuvieron también una participación relevante que influyó, en algunos casos, en la propia organización diplomática de la monarquía. Principalmente los encontramos mencionados en las embajadas de tres formas distintas: como secretarios, como doctores y como embajadores.

Los secretarios de embajada están claramente documentados en las misiones enviadas a los Concilios del siglo XV, donde se les menciona con ese cargo concreto. Así, los tenemos localizados en Constanza, Siena y Basilea. En el caso de Constanza actuó como tal Pedro Fernández de Cámara, personaje ya conocido, que era ya secretario real y que actuó como secretario de la legación y como tal se especificaba en su nombramiento ${ }^{39}$. En Siena fue Enrico Schulte, secretario real de origen neerlandés, que actuó a la vez como secretario del presidente de legación y como notario de la misma ${ }^{40}$. Y en Basilea, por último, fue Juan González de la Maina (o de Atienza), también secretario real ${ }^{41}$. Como vemos, son nombrados secretarios de las legaciones por el monarca (claramente documentado en dos de ellos), pero es más significativo el hecho de que todos eran, además, secretarios reales. Un nuevo dato curioso, de nuevo nos encontramos un 
eclesiástico, embajador y secretario regio que actúa también al servicio de los arzobispos de Toledo: Enrico Schulte.

No es la única ocasión en la que encontramos a eclesiásticos actuando como secretarios de una embajada. Así, por ejemplo, en 1422 estaba en Portugal, negociando junto a Alfonso de Cartagena, y posiblemente en calidad de secretario de la legación, Juan Alfonso de Zamora ${ }^{42}$. No es baladí: también era secretario regio. También tuvo un papel relevante como notario de una legación castellana Gonzalo González Capoche, en las negociaciones de Ágreda de 1431, donde actuó, además, junto a un aragonés, como fedatario de todas las negociaciones ${ }^{43}$.

¿Hubo más secretarios de embajadas eclesiásticos? Es muy plausible que sí, sin embargo, en pocas ocasiones, como vemos, hay mención expresa. Parece lógico que en las misiones más amplias e importantes ocurriese así, como es el caso de los concilios o de negociaciones de paz de cierta importancia; pero es difícil estimarlo en el conjunto de las embajadas que, normalmente, no eran ni tan duraderas ni contaban con tanto personal. De todas formas, podemos ver que muchos eclesiásticos embajadores eran secretarios regios, pero los que mencionaremos actuaban como lo primero y no tanto como secretarios de embajada.

Además de secretarios de embajada en muchas ocasiones nos encontramos otros eclesiásticos sirviendo en embajadas. En muchas ocasiones es difícil deslindar quienes acudían como embajadores y quiénes como servidores de la embajada, dado el carácter de las fuentes. En las ocasiones en que se conservan las cartas de creencia y nombramiento, lo que no es nada habitual en el caso castellano, podemos delimitar claramente quiénes eran nombrados como embajadores. Con ello el resto del personal que aparece mencionado en ocasiones podemos considerarlo como servidores de otro tipo de las embajadas. Normalmente actuaban como consejeros y colaboradores en un sentido amplio, la mayor parte de las veces por su formación jurídica. Es por ello que encontramos muchos doctores y licenciados entre ellos. No hay estudios estadísticos al respecto, con lo que hemos de conformarnos con mostrar algunos ejemplos. Por ejemplo, los letrados suponían el $36 \%$ de los enviados castellanos a Portugal en la primera mitad del siglo XV, frente al $26 \%$ de eclesiásticos titulados ${ }^{44}$; sin embargo, hay que tener en cuenta que muchos de esos letrados, que actuaban como doctores o licenciados, también eran eclesiásticos, beneficiados, canónigos e incluso prebendados. Un buen ejemplo es Juan Alfonso de Zamora, que era secretario real, pero también canónigo de León ${ }^{45}$. De cualquier forma, en la mayor parte de las ocasiones es difícil deslindar este tipo de personal de los embajadores.

Los embajadores, pues, eran el principal elemento de las misiones diplomáticas y entre ellos es muy habitual encontrar eclesiásticos. Con su servicio ayudaron a construir, como poco, la diplomacia regia por medio de su desarrollo cotidiano. Es muy habitual encontrar eclesiásticos de todo tipo dentro de este grupo, del que ya se ha realizado algún análisis de forma general (aunque los resultados sean, sin duda, revisables en cuanto a las cifras, a la luz de nueva documentación ${ }^{46}$ ). Sin embargo, nos sirve al menos para comprobar el elevado número de eclesiásticos que, a lo largo del siglo XV, actuaron al servicio de la monarquía en el ámbito diplomático: un total de $90^{47}$. Analizar el papel de cada uno de ellos sería extenso y no hay lugar aquí para ello. Del mismo modo, analizar el rol en cada una de sus embajadas daría lugar a algo más que una monografía, trabajo que, además, está en gran parte por hacer. Sin embargo, hubo algunas de esas participaciones de eclesiásticos en embajadas que brillan con luz 
propia, y que supusieron un avance importante en la construcción de los aparatos monárquicos y de la imagen monárquica. Algunas de esas misiones diplomáticas, dirigidas por eclesiásticos, supusieron auténticos ejemplos a imitar en cuanto al trabajo realizado.

\section{Las misiones ejemplares}

29 Efectivamente algunas de las embajadas llevadas a cabo por eclesiásticos pueden ser tomadas como auténticas misiones ejemplares por el hecho de suponer un notable avance en alguno de los aspectos que interesaban a la monarquía. En general podemos ver que brillan por la capacidad de dirigir la negociación y la delegación castellana, en otras ocasiones por la elaboración de una defensa específica de la posición de su monarca y reino. También hay misiones que destacan por la construcción de una imagen determinada del rey castellano (principalmente de cara a la escena internacional: la magnificencia regia de la entrada en Basilea, por ejemplo; o la defensa de la prelación castellana). Sea como fuere, en muchas de esas ocasiones nos sirven para ver el funcionamiento interno de esa diplomacia.

En este sentido analizaremos aquí, aunque sea someramente, algunas de esas misiones ejemplares dirigidas por eclesiásticos y que suponen, desde nuestro punto de vista, un momento de especial relevancia en la organización de la diplomacia. Misiones que destacan desde dos puntos de vista concretos y que atañen al interés del presente estudio: la organización concreta del trabajo diplomático. Misiones que fueron imitadas a posteriori, lo que confirma, efectivamente, que supusieron un jalón en la construcción del aparato regio. Como veremos, en algunos casos el conocimiento que tenemos de estas misiones se debe a la excepcional conservación de fuentes documentales.

\section{La construcción de una imagen simbólica}

31 Como se ha comentado en diversas ocasiones una embajada sirvió para crear, defender o ensalzar una imagen determinada de la monarquía castellana. Esto tenía una utilidad clara en el ámbito internacional: el mostrar al rey y reino de Castilla con una entidad determinada dentro del juego político de Europa occidental. Esto supuso, en algunas ocasiones, una auténtica preocupación para la monarquía ${ }^{48}$, y sabemos que algunas legaciones tuvieron especial cuidado (y tenían órdenes al respecto) para que la posición castellana no se viese menoscabada ${ }^{49}$.

En este caso, nos encontramos con varias misiones en las que se produjo una defensa de la preeminencia castellana. A lo largo de los sucesivos conflictos se ha visto cómo se tenía conocimiento del estado de la cuestión en anteriores misiones, con lo cual muestran la preocupación regia porque esa posición e imagen del reino castellano no se viese menoscabada. En ellas, además, por medio de la labor de los embajadores al frente de la misión, se iba construyendo y presentando en el ámbito internacional una visión determinada del reino. Son tres las misiones que destacan en este aspecto, y todas fueron dirigidas por un eclesiástico: la misión en la Curia de Álvaro de Isorna de 1422; la del Concilio de Siena de 1423-1424 dirigida por Juan Martínez Contreras, arzobispo de Toledo; y la de Alfonso de Cartagena en el Concilio de Basilea de 1434 a $1438^{50}$. 
33 Álvaro de Isorna, obispo de Cuenca, encabezó la misión dirigida por el rey ante el papa para presentar una serie de solicitudes y oponerse, a su vez, a la misión enviada por el infante Enrique ${ }^{51}$. Sin embargo, en el transcurso de la misma el obispo tuvo que hacer frente a un enfrentamiento con los enviados ingleses por la preeminencia de ambos reinos. Castilla alegaba precedencia sobre Inglaterra, lo que llevó, incluso, al enfrentamiento violento de los embajadores ${ }^{52}$. En dos ocasiones Álvaro de Isorna se opuso a que los ingleses tuviesen precedencia sobre los castellanos: en las celebraciones litúrgicas de la fiesta de la Candelaria, y en las celebraciones de la Pascua ${ }^{53}$. En este caso nos encontramos con una misión que supuso un antecedente para otras posteriores dado que por primera vez se enfrentaban castellanos e ingleses por la posición de cada reino.

Más relevante, en cuanto a la construcción ideológica, fue la misión encabezada por Juan Martínez Contreras en Siena ${ }^{54}$. En esa reunión conciliar de nuevo surgieron los roces entre los embajadores ingleses y, de una forma más amplia, los hispanos. A lo largo del mismo el primado toledano organizó la defensa de la posición hispana por medio de la elaboración de los discursos en los que se sostenía la primacía hispana (aunque en ocasiones se deslizaba el caso castellano). En esta ocasión nos encontramos con una construcción ideológica para defender la primacía hispana, elaborada por el presidente de la legación (aunque indicaba que con el apoyo de doctores de la embajada). Con el uso de la historia, de la geografía eclesiástica y de la legislación pontificia y conciliar el embajador castellano buscaba mostrar la superioridad hispana, basando en ello las razones para la preeminencia ${ }^{55}$. De esta forma, aunque se basaba en un conflicto semejante de Constanza (que fue gestionado por los embajadores franceses principalmente), Martínez Contreras tuvo un papel ciertamente relevante y por primera vez Castilla era tomada como actor en ese discurso, en el que se mostraba conocer lo ocurrido en Constanza ${ }^{56}$.

La más relevante de las actuaciones de este tipo, sin embargo, es la conocida de Alfonso de Cartagena en el entorno cronológico del Concilio de Basilea. En primer lugar, por la continuación de la defensa de la preeminencia ante Inglaterra (ahora ya exclusivamente castellana) y que se llevó a cabo en el mismo Concilio. Y en segundo lugar por llevar a cabo el mismo papel en la defensa de la posesión castellana de las islas Canarias, frente a Portugal, que se llevó a cabo en la Curia pontificia radicada en Florencia ${ }^{57}$. Recordemos que fue él el que realizó los alegatos castellanos en ambas cuestiones, demostrando su erudición y capacidad dialéctica a lo largo de los mismos ${ }^{58}$. A lo largo de ambas piezas (una compuesta como un discurso y la segunda como una prueba jurídica) Alfonso de Cartagena utilizó todo su saber histórico y jurídico, así como su experiencia diplomática, para defender los intereses castellanos, presentando con ello una imagen determinada de los derechos del reino ${ }^{59}$.

Estos son tres buenos ejemplos de cómo los eclesiásticos al frente de la legación podían asumir un papel principal en la defensa de la posición del rey de Castilla en el exterior, con lo que colaboraban en la construcción de una imagen simbólica del reino y su monarca. Lo relevante, además del hecho de su propia participación, es que nos muestran una forma de trabajar siguiendo una línea determinada con el paso de los años. Así, vemos cómo de la defensa que hace Álvaro de Isorna en la curia en 1422, basada simplemente en la preminencia y en evitar que se vea menoscabada la posición castellana, se pasó a una defensa sistemática utilizando el derecho, la cultura y la historia. Esto, que ya lo vemos en el trabajo de Juan Martínez Contreras en Siena llegó a 
su punto más elevado con Alonso de Cartagena en Basilea, al profundizar en las líneas marcadas por el arzobispo toledano. Así, entre la dialéctica (ya fuese verbal o física) y la elocuencia, los eclesiásticos participaron en esa construcción paulatina.

Asistimos, así, a una paulatina evolución y mejora en la línea trazada con anterioridad. Esto denota el conocimiento de lo que había ocurrido en casos anteriores, así como la preparación de las embajadas de forma cuidadosa, atendiendo a las posibles necesidades. Así, por ejemplo, sabemos que Juan Martínez Contreras y Alonso de Cartagena contaron con materiales procedentes de las misiones anteriores (como las actas de los concilios y obras de diverso tipo que podían ser utilizadas y mencionadas en sustento de sus teorías ${ }^{60}$ ). Eso nos lleva a lo que parece más relevante en el sentido de este trabajo: nos muestra cómo había una continuidad en el trabajo diplomático. Se conservaba y consultaba la documentación de misiones anteriores, como forma de garantizar el éxito de una misión. La repetición de temas y líneas de acción lo demuestra, como veremos a continuación y nos muestra claramente esa segunda faceta de la participación activa de los eclesiásticos en la construcción de ese aparato diplomático.

\section{La organización y funcionamiento de la base diplomática}

De esta forma, al hilo de lo que las fuentes nos muestran podemos ver cómo se estaba llevando a cabo toda una organización de la función diplomática. Estas "misiones ejemplares" nos sirven en ocasión para conocer mejor ese funcionamiento y podemos apreciar, como se verá, que en todo ello hubo algunos eclesiásticos que tuvieron, como colaboradores regios, un papel de cierto peso.

Un papel que les venía dado por el hecho de que fuesen los presidentes de la legación, de iure o de facto, es decir, hubiesen sido nombrados como tal o no, puesto que hay ocasiones en las que no se conserva un nombramiento como tal en el que se especifique que actúan como cabeza de la misma ${ }^{61}$. Sea como fuere, lo cierto es que actúan como tal y con esa actuación nos muestran su labor y organización de la misión lo que, en ocasiones, fue imitado a posteriori como veremos.

40 A la hora de atender a cómo lo hicieron podemos llegar a vislumbrar tres aspectos distintos: preparación de la embajada, organización de la misión y organización de los testimonios de lo que se había hecho.

41 En la preparación de la embajada tuvieron que tener un papel fundamental. Podemos sospechar una preparación previa (algo lógico) por los materiales que utilizan a lo largo de su misión, que debieron ser llevados por ellos desde Castilla. Esto se puede identificar en los materiales que se mencionan y que utilizaban en sus tareas diplomáticas. Como se ha comentado al hilo de la creación de una imagen del reino castellano, estos solían proceder de reuniones anteriores $\mathrm{y}$, a veces, son claramente identificables: actas, obras jurídicas e históricas...

Así, por ejemplo, en 1422 Juan Martínez Contreras, enviado a la Curia a Roma, impartía órdenes a los embajadores que iban a hablar ante el papado aportando documentación regia. Es decir, se había recopilado previamente lo que pudiese ser necesario y lo había llevado consigo a Roma ${ }^{62}$. Esto entra dentro de lo que podríamos pensar como algo básico: llevar los materiales necesarios para la misión; pero en muchas ocasiones se iba 
más allá y se era previsor. Por ejemplo, sabemos que el mismo Juan Martínez Contreras, ya en el Concilio de Siena de 1424, y como presidente de la natio hispana, tenía a su disposición obras históricas y las actas del Concilio de Constanza ${ }^{63}$. Para todo ello tuvo que contar, sin duda, con la colaboración del secretario regio Enrico Schulte. Material que, como sabemos, se utilizó para la elaboración de diversos textos.

El mismo Juan Martínez Contreras acudió a las negociaciones en la frontera de Ágreda con Navarra y Aragón, y de nuevo aparece gestionando toda la comunicación con los embajadores rivales (a ellos les escribe en diversas ocasiones), así como la propia (en las actas de la negociación se reflejan sus poderes y los de sus compañeros de embajada) ${ }^{64}$.

Ejemplo capital de todo ello es el ya mencionado Concilio de Basilea. Gracias a los trabajos que allí realizó Cartagena (su defensa de la preeminencia castellana y del derecho de propiedad sobre Canarias), sabemos que contaba con diversas obras históricas (algunas ya utilizadas por Martínez Contreras en Siena), con las actas de los concilios de Siena y de Constanza... Además, sabemos que conocía los discursos de Siena, pues utiliza los mismos recursos y ejemplos ${ }^{65}$. En el material preparado para la defensa de la propiedad castellana de las Canarias nos encontramos de nuevo con la muestra de ese aporte de obras posiblemente necesarias para cumplir su misión, en este caso con un mayor peso del carácter jurídico ${ }^{66}$, aunque utiliza obras como las Etimologías de Isidoro de Sevilla ${ }^{67}$, también textos jurídicos como el Codex Iustiniani o textos históricos de Landulfo de Colonia ${ }^{68}$.

Obviamente, en la organización de la propia misión diplomática tenían un papel fundamental, y de nuevo podemos rastrear en esas misiones el buen trabajo realizado. Por ejemplo, Juan Martínez Contreras dio instrucciones a los emisarios que iban a hablar ante el papa $^{69}$. En ellas había cuestiones concretas en las que se maneja la información. Se indicaba, por ejemplo, cómo se debían comunicar las cuestiones al papa, ocultando o manejando los datos y hechos (en un juego de información y desinformación muy interesante ${ }^{70}$ ): indicaba que debían ser escuchados primero, que consiguiesen que el tema no se tratase en público y solo en consistorio secreto (donde realizaría un curioso alegato contra el entorno de la Curia $^{71}$ ). Es decir, muestra un claro control del funcionamiento de la misión.

Parecido papel desempeñaba de nuevo Martínez Contreras poco después en Siena, aunque en esta ocasión era incluso más relevante, al asumir la cabeza de la natio hispana, que englobaba en el Concilio a todos los reinos peninsulares. Sin embargo, incluso como tal demostró que era capaz de hacerse cargo de la organización. Así, por ejemplo, le vemos aceptar a los embajadores aragoneses ante el Concilio aunque fuesen laicos, utilizando la misma fórmula empleada en Constanza. En esto, además, sirvió también a los intereses castellanos, pues en tal Concilio Aragón no contaba con los votos de sus sedes italianas y, con ello, la primacía de la natio quedaba en Castilla ${ }^{72}$. Además, actuó en nombre de esta y como su representante en los actos conciliares, lo que le situó en una posición relevante. Y ahí supo desenvolverse con soltura, consciente de su posición y de lo que eso suponía. Buen ejemplo es la cuestión del doble voto que exigió (y que utilizó) a la hora de elegir la sede del siguiente Concilio: uno como primado (que equivalía a patriarca) y otro como presidente de la natio hispana ${ }^{73}$, además de muchos otros actos en los que participó y tuvo un papel fundamental ${ }^{74}$. Su principal labor organizativa, sin embargo, se pudo apreciar en el conflicto con Inglaterra donde, junto a doctores de legación peninsular, se encargó de presentar y defender su posición ${ }^{75}$. 
47 En este arzobispo tenemos, sin lugar a dudas, a uno de los principales eclesiásticos al servicio diplomático de Castilla de los años 20 y 30 del siglo XV. Sus buenas labores fueron apreciadas por Juan II, razón por la que actuaría en diversas ocasiones, como vemos. Aún después de Siena participó en diplomacia, y de nuevo al frente de una misión amplia y complicada, en este caso las negociaciones con Aragón y Navarra de 1430 a 1433. En este caso nos encontramos con uno de los casos de los que tenemos una excepcional documentación que nos permite un conocimiento único sobre su funcionamiento y el papel de un eclesiástico en ella. Pese a que aún conocemos poco, supuso un nuevo reto organizativo para Juan Martínez Contreras, era una misión amplia en el tiempo, con numeroso personal, y en la que la negociación a tres bandas y con múltiples problemas que se mezclaron complicaron su evolución ${ }^{76}$.

48 A lo largo de esta misión Juan Martínez Contreras tuvo que ordenar una amplia embajada, que por la peste que se declaró en Ágreda tuvo que repartirse entre diversas localidades menores de la frontera ${ }^{77}$, que afrontó un largo periodo de negociaciones (con la consiguiente renovación de poderes ${ }^{78}$ ), que negoció tanto en Tarazona como con los representantes de los reyes situados en diversos lugares (se conservan actas de negociación ${ }^{79}$ y decenas de cartas enviadas por Martínez Contreras a los diversos delegados de Aragón o Navarra, o a los mismos monarcas ${ }^{80}$ ). Es decir, el arzobispo de Toledo en esta ocasión, sin duda con la colaboración de los burócratas del monarca que le acompañaron (desde un secretario real, Gonzalo González Capoche ${ }^{81}$ a oidores de la Audiencia o un refrendario ${ }^{82}$ ), demostró de nuevo una notable capacidad de organización de una misión diplomática que, debido a su muerte, no vio culminar.

49 Y un último ejemplo de la capacidad organizativa de los eclesiásticos en las misiones diplomáticas lo tenemos de nuevo en Basilea. En esta ocasión Alonso de Cartagena es quien la dirigió de hecho, como se ha dicho, y el que aparece ordenando qué debe hacerse y cuándo. Casi se podría decir que, incluso, el obispo Isorna, que era superior en jerarquía y tenía también experiencia diplomática, seguía sus instrucciones. En este caso, además, contó con la colaboración de Juan González de la Maina a la hora de todo el manejo documental. En este caso nos encontramos de nuevo con un conjunto de fuentes excepcional, que nos permite conocer mejor cómo pudo organizarse y trabajar esa legación, en este caso guiada por un eclesiástico y con un secretario también eclesiástico. Se conservan las cartas de nombramiento, documentación que recibió la embajada, la comunicación con otras embajadas presentes en el Concilio, materiales organizados por Cartagena para la defensa de los intereses castellanos (la precedencia y el caso de las Canarias)... La mayor parte de ello recopilado en el famoso volumen K1711 del Archivo General de Simancas.

¿Acaso este volumen es un ejemplo de cómo trabajaban esas embajadas? ¿La recopilación de información que se produce en ese legajo pudo ser el fruto del trabajo de Cartagena y del secretario González de la Maina, en su afán por dejar testimonio de todo el trabajo realizado para que luego se pudiese informar al monarca? ${ }^{83}$

51 Se ha podido comprobar, de hecho, que en algunas de estas embajadas que se han ido describiendo los embajadores contaban con material y conocimiento de anteriores misiones. ¿Acaso cada misión realizó el mismo trabajo y esos materiales pudieron ser consultados por los embajadores antes de partir? ¿Podría ser que el legajo K1711 no fuese más que uno de muchos, pero sí el único que se nos ha conservado? Como se ve son muchas preguntas e hipótesis más o menos lógicas pero, de momento, de difícil respuesta. Lo cierto es que sí parece plausible pensar que efectivamente en los archivos 
regios se conservase la documentación de misiones anteriores y que esta era consultada en aras de preparar mejor la misión que se encomendaba a los embajadores (lo que explicaba que fuesen preparados para determinadas cuestiones y conflictos conociendo los hechos pasados, o que Cartagena reutilizase temas empleados por Martínez Contreras, y este por los franceses en Constanza). Esa documentación, como es el caso del K1711 nos permite observar cómo se organizaba esa diplomacia y cómo funcionaba. Por casualidad, de nuevo, es por un eclesiástico.

\section{Conclusiones}

A lo largo del presente trabajo se ha analizado cómo los eclesiásticos participaron de forma activa en la construcción del aparato diplomático castellano. Aún conocemos muy poco del mismo y casi se ha ido construyendo a la par que este relato en algunas cuestiones, pero no cabe duda que ya desde el siglo XIV algunos eclesiásticos tuvieron un papel muy activo en el desarrollo de esa diplomacia.

Es obvio que su papel lo desempeñaban por su condición de servidores regios, y no como eclesiásticos. También que sus conocimientos y estudios era lo que les capacitaba para el desarrollo de esas funciones, así como su propia valía. Pero aun así es evidente que esos clérigos participaron en la construcción paulatina de un aparato de gobierno de la monarquía de tanto peso como era la diplomacia.

De esta forma hemos podido ver cómo de forma paulatina se fue produciendo una especialización en el ámbito de la administración regia, que en el caso castellano se detecta en el ámbito del latín, que acabó desembocando en una estructura bastante relevante a mediados del siglo XIV, con la existencia del notario mayor de latín. En esos puestos, además, encontramos usualmente a eclesiásticos que servían al monarca. ¿Y antes de principios del siglo XIV? No tenemos datos todavía, pero sin duda hemos de seguir buscando, pues la presencia de especialistas en latín en la cancillería regia de Alfonso X con una especial participación en diplomacia nos hace sospechar que ya entonces estaba iniciándose ese procedimiento. Nos falta encontrar datos más concretos y específicos o realizar una estadística más completa que nos permita llegar a conclusiones más firmes.

Con la primera guerra civil castellana y la llegada de la dinastía Trastámara nos encontramos el fin de esa estructura, al desaparecer los notarios mayores de latín. Sin embargo, poco a poco se irá reconstruyendo con unas fechas que nos son bastante desconocidas. Reconstruyéndose y tomando nueva forma por medio de escribanos de latín y ya en el XV con secretarios de latín. La unión de esta figura con secretarios regios nos permite ver cómo se une a la más estrecha colaboración con el monarca (algo lógico si tenemos en cuenta que la diplomacia podía tener una importancia capital). De nuevo en estos puestos localizamos a eclesiásticos de forma muy habitual, si no constante. Aún no sabemos claramente cuándo y cómo se desarrolló de forma efectiva, tampoco su organización funcional, pero paulatinamente vamos teniendo pruebas y rastros que nos permiten hacer un dibujo siquiera esquemático de su funcionamiento.

Pero, además, se ha visto cómo los eclesiásticos colaboraban también en el desarrollo de la propia diplomacia y cómo, a través de ella, se iba perfilando una forma de trabajo determinada. Esas formas de trabajo, además, podemos sospechar (al menos hasta que existan más pruebas) que fueron desarrollándose gracias al aporte de alguno de esos 
eclesiásticos. La documentación existente al menos nos permite en algunos casos concretos (y gracias a conjuntos ciertamente excepcionales) ver cómo algunas cuestiones y usos eran repetidos de una misión a la otra (sin duda por la conciencia de su buen funcionamiento), pero también mejorados.

Gracias a ello las figuras de Juan Martínez Contreras y Alonso de Cartagena se muestran como dos grandes organizadores de embajadas. Si en el caso del segundo era más conocido, no es así sobre el primero de ellos, a quien, poco a poco, vamos conociendo más y mejor y de quien en el futuro seguramente conoceremos más. De esta forma, con los nuevos aportes documentales que se van realizando y con el nuevo análisis y reinterpretación de los que ya teníamos avanzamos poco a poco en un mejor conocimiento de la diplomacia regia. Y con ello, se nos va mostrando claramente cómo los eclesiásticos participaron de forma activa en todo el proceso colaborando con el monarca y adoptando, en ocasiones, papeles fundamentales.

\section{BIBLIOGRAFÍA}

Fuentes manuscritas

ACA, Cancillería, Cartas Reales, Alfonso IV [V], 1514 hasta 2413.

ACA, Cancillería, Reg. 557.

ACA, Cartas Reales, Jaime I, caja 1.

ACT, A-8. L.1.1. ; I.11.3.C.62.

AGS, Estado-Francia, K. 1711

AGS, Patronato Real, caj. 21, no 9 .

BNE, mss. 7815 y 13018.

AHNob, Osuna, C. 3484, doc. 22.

Fuentes impresas

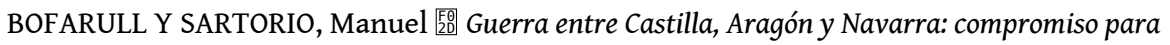
terminarla (año 1431). Barcelona: Colección de Documentos Inéditos del Archivo de la Corona de Aragón, 1869.

CAÑAS GÁLVEZ, Francisco de Paula 粮 Colección diplomática de Santo Domingo el Real de Toledo. Documentos Reales I. 1249-1473. Madrid: Sílex ediciones, 2010.

Cortes de los antiguos reinos de León y Castilla. Madrid: Real Academia de la Historia, 1861, vol. 1. DÍAZ MARTÍN, Luis Vicente 膯 Colección documental de Pedro I de Castilla (1350-1369), Salamanca: Junta de Castilla y León, 1999, vol. 3.

ECHEVARRÍA GAZTELUMENDI, María Victoria 国品 Edición crítica del Discurso de Alfonso de Cartagena "Propositio super altercatione praeminentia sedium inter oratores regum castellae et angliae in 
Concilio Basiliense", versiones en latín y castellano. Madrid: Universidad Complutense, Servicio de Reprografía, 1992.

GALÍNDEZ DE CARVAJAL, Lorenzo (comp.) 医 Crónica del serenísimo príncipe don Juan, en Crónicas de los Reyes de Castilla. Madrid, 1877, en el volumen 69 de la Biblioteca de Autores Españoles.

GONZÁLEZ ROLÁN, T.; HERNÁNDEZ GONZÁLEZ, F.; SAQUERO SUÁREZ-SOMONTE, P. F. humanismo en el siglo XV Edición crítica, traducción y notas de las «Allegationes super conquesta Insularum Canariae contra portugalenses» de Alfonso de Cartagena. Madrid: UNED, Universidad Nacional de Educación a Distancia, 1994.

RYMER, Thomas 㕄 Foedera, conventiones, litterae, et cujuscunque generis acta publica, inter reges Angliae et alios quosvis imperatores, reges, pontifices, principes, vel communitates: ab ingressu Gulielmi I. in Angliam, A.D. 1066, ad nostra usque tempora habita aut tractata. Londres, 1816-1869, vol. I-1, Estudios

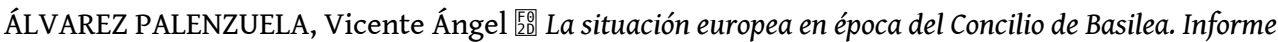
de la delegación del reino de Castilla. León: Centro de Estudios e Investigación San Isidoro, 1992.

BECEIRO PITA, Isabel [E⿱ ${ }_{20}$ “La consolidación del personal diplomático entre Castilla y Portugal (1392-1455).” in GONZÁLEZ JIMÉNEZ, Manuel (ed.) 澄 La península ibérica en la era de los descubrimientos 1301-1492. Actas de las III jornadas hispano portuguesas de Historia Medieval. Sevilla: 1997, pp. 1735-1744.

BELTRÁN DE HEREDIA, Vicente, "Nuevos documentos inéditos sobre el poeta Juan de Mena". Salmanticensis 3-1 (1956), pp. 502-508.

BRANDMÜLLER, Walter [20] Das Konzil von Pavia-Siena. Munster: Aschendorf, 1968-1974, vol. 2.

CARTAGENA, Alfonso de 夙 "Discurso sobre la precedencia del rey Católico sobre el de Inglaterra en el Concilio de Basilea." in PENNA, Mario (ed.) ${ }_{20}^{\circ}$ Prosistas castellanos del siglo XV. Vol. I. Madrid: Atlas, 1959.

CAÑAS GÁLVEZ, Francisco de Paula, "La diplomacia castellana durante el Reinado de Juan II: la participación de los letrados de la cancillería real en las embajadas regias". Anuario de estudios medievales 40-2 (2010), pp. 691-722.

CAÑAS GÁLVEZ, Francisco de Paula 20 Burocracia y cancillería en la corte de Juan II de Castilla (1406-1454) estudio institucional y prosopográfico. Salamanca: Ediciones Universidad de Salamanca, 2012

CAÑAS GÁLVEZ, Francisco de Paula 活 “Juan de Mena: secretario de latín y cronista del rey." in MOYA GARCÍA, Cristina (ed.) 皿 Juan de Mena. De letrado a poeta. Woodbridge: Tamesis books, 2015, pp. 11-22.

CHAPLAIS, Pierre [5: Essays in Medieval Diplomacy and Administration. Londres, Hambledon, 1981.

CUTTINO, George Peddy ${ }_{20}^{20}$ English Diplomatic Administration, 1259-1399. Londres: Oxford University Press, 1940.

DÍAZ MARTÍN, Luis Vicente 㡠 Los orígenes de la Audiencia Real castellana. Sevilla: Universidad de Sevilla, 1997.

DIOS, Salustiano de 5 El El Consejo Real de Castilla (1285-1522). Madrid: Centro de Estudios Constitucionales, 1982.

FERNÁNDEZ GALLARDO, Luis 㹂 Alonso de Cartagena (1385-1456). Una biografía política en la Castilla del siglo XV. Valladolid: Junta de Castilla y León, 2002. 
FERNÁNDEZ GALLARDO, Luis 智 Alonso de Cartagena. Iglesia, política y cultura en la Castilla Castilla del siglo XV, Madrid: Universidad Complutense de Madrid, 1998, pp. 924-1004. Tesis doctoral. [consultada el 12 junio 2020]. Disponible en http://eprints.ucm.es/2509/.

FERRER I MALLOL, María Teresa ${ }_{20}^{2}$ Entre la paz y la guerra. La Corona catalano-aragonesa y Castilla en la Baja Edad Media. Barcelona: CSIC, 2005.

GARRIGA ACOSTA, Carlos Antonio [20 La Audiencia y las chancillerías castellanas (1371-1525): historia política, régimen jurídico y práctica institucional. Madrid: Centro de Estudios Constitucionales, 1994.

GÓMEZ REDONDO, Fernando [⿰氵巨⿹勹巳巳寸 Historia de la prosa medieval castellana. III. Los orígenes del humanismo. El marco cultural de Enrique III y Juan II. Madrid: Cátedra, 2002.

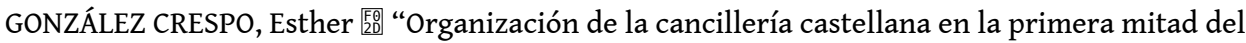
siglo XIV”. En la España Medieval 8 (1986), pp. 447-470.

GOÑI GAZTAMBIDE, José 㡠 “Los españoles en el Concilio de Constanza II”. Hispania Sacra 16 (1963), pp. 106-200.

KLEINE, Marina 㹂 La cancillería real de Alfonso X: actores y prácticas en la producción documental. Sevilla: Universidad de Sevilla, 2015.

LADERO QUESADA, Miguel Ángel [ [20 La Hacienda Real de Castilla (1369-1504). Madrid: Real Academia de la Historia, 2009.

MARTÍN PRIETO, Pablo [ [20 “Invención y tradición en la cancillería de Alfonso VIII de Castilla (1158-1214)”. Espacio, Tiempo y Forma. Serie III Historia Medieval 26 (2013), pp. 209-244.

MOEGLIN, Jean-Marie ; PÉQUIGNOT, Stéphane 医 Diplomatie et «relations internationales» au Moyen Âge (IX-XV siècles). París: Presses Universitaires de France, 2017.

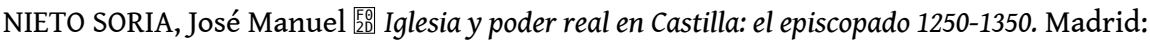
Universidad Complutense, 1998.

PECQUIGNOT, Stéphane ${ }_{20}^{\circ}$ Au nom du roi. Pratique diplomatique et pouvoir durant le règne de Jacques II d'Aragon (1291-1327). Madrid: Casa de Velázquez, 2009.

SERRANO, Luciano ${ }_{20}$ Los conversos don Pablo de Santamaría y Alonso de Cartagena. Obispos de Burgos, gobernantes, diplomáticos y escritores, Madrid: CSIC, 1942.

STREET, Florence 澄 “La vida de Juan de Mena”. Bulletin Hispanique 55-2 (1953), pp. 154-155.

VERDON, Jean

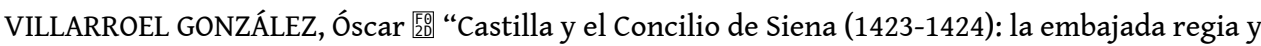
su actuación”. En la España Medieval 30 (2007), pp. 131-172.

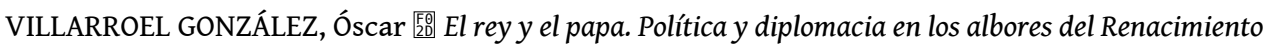
(el siglo XV en Castilla), Madrid: Sílex ediciones, 2009.

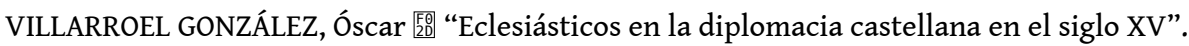
Anuario de Estudios Medievales 40-2 (2010), pp. 791-819.

VILLARROEL GONZÁLEZ, Óscar [20 El rey y la Iglesia castellana. Relaciones de poder en época de Juan II. Madrid: Fundación Ramón Areces, 2011.

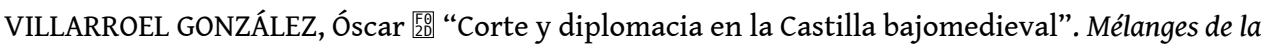
Casa de Velázquez. Nouvelle série 45-2 (2015), pp. 105-124. 
VILLARROEL GONZÁLEZ, Óscar 栚 “Autoridad, legitimidad y honor en la diplomacia: los conflictos anglo-castellanos en los concilios del siglo XV". Espacio, Tiempo y Forma. Serie III Historia Medieval 29 (2016), pp. 777-813.

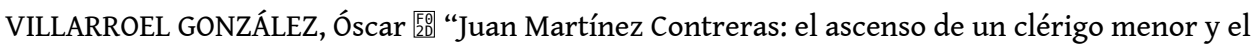
servicio regio." in VILAR, Hermínia Vasconcelos; BRANCO, Maria João (eds.) 渞 Ecclesiastics and political state building in the Iberian monarchies, 13th-15th centuries. Lisboa: Publicações do Cidehus, 2016 [Consultado el 17 octubre 2019]. Disponible en http://books.openedition.org/cidehus/1539.

VILLARROEL GONZÁLEZ, Óscar 㯺 “Alvaro Núñez de Isorna: un prelado y el poder”. Edad Media. Revista de Historia 18 (2017), pp. 263-292.

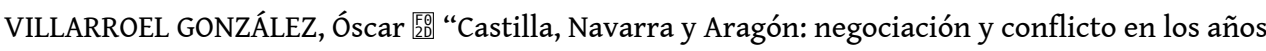
30 del siglo XV.” in NIETO SORIA, José Manuel; VILLARROEL GONZÁLEZ, Óscar (coords.) 温 Comunicación y conflicto en la cultura política peninsular (siglos XIII al XV). Madrid: Sílex, 2018, pp. 83-112.

VILLARROEL GONZÁLEZ, Óscar 旍 “Comunicar y negociar por el rey: los eclesiásticos al frente de embajadas en la diplomacia castellana (siglos XIII al XV)” in VIGIL MONTES, Néstor (dir.) F0 Comunicación política y diplomacia en la Baja Edad Media. Évora: Publicações do Cidehus, 2019 [Consultado el 17 octubre 2019]. Disponible en http://books.openedition.org/cidehus/6979.

ZALDÍVAR, Antonio 原 Language and Power in the Medieval Crown of Aragon: The Rise of Vernacular Writing and Codeswitching Strategies in the Thirteenth-Century Royal Chancery. Los Angeles: Universidad de California en Los Ángles, 2014. Tesis doctoral.

\section{NOTAS}

1. Puede verse: VILLARROEL GONZÁLEZ, Óscar ${ }_{20}^{\text {[E }}$ “Eclesiásticos en la diplomacia castellana en el siglo XV". Anuario de Estudios Medievales 40-2 (2010), pp. 791-819.

2. Véanse las apreciaciones que realiza PÉCQUIGNOT, Stéphane [.0. diplomatique et pouvoir durant le règne de Jacques II d'Aragon (1291-1327). Madrid: Casa de Velázquez, 2009, pp. 1-8.

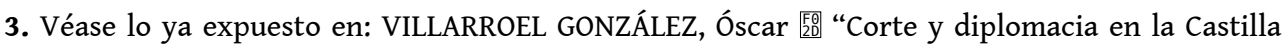
bajomedieval”. Mélanges de la Casa de Velázquez. Nouvelle série 45-2 (2015), pp. 105-124, en concreto pp. 110-113.

4. CUTTINO, George Peddy [F⿱ ${ }_{20}$ English Diplomatic Administration, 1259-1399. Londres: Oxford University Press, 1940; CHAPLAIS, Pierre 延 Essays in Medieval Diplomacy and Administration. Londres: Hambledon, 1981.

5. MOEGLIN, Jean-Marie; PÉQUIGNOT, Stéphane 嚂 Diplomatie et «relations internationales» au Moyen Âge (IX-XV siècles). París: Presses Universitaires de France, 2017, pp. 145 y ss.

6. Por ejemplo, como las razones para su importancia en la diplomacia: dominio del latín, el peso

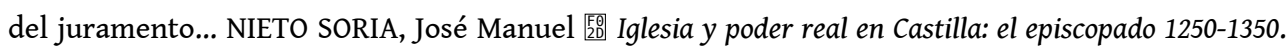
Madrid: Universidad Complutense, 1998, pp. 48-58.

7. Buen ejemplo es la misma nómina de embajadores. A las ya realizadas (véase, por ejemplo:

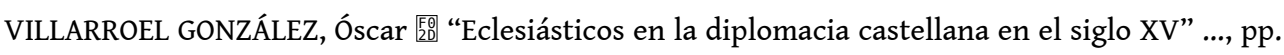
792-801; VILLARROEL GONZÁLEZ, Óscar 海 “Comunicar y negociar por el rey: los eclesiásticos al frente de embajadas en la diplomacia castellana (siglos XIII al XV)". in VIGIL MONTES, Néstor (dir.) 递 Comunicación política y diplomacia en la Baja Edad Media. Évora: Publicações do Cidehus, 2019 [Consultado a 17 Octubre 2019]. Disponible en http://books.openedition.org/cidehus/6979. Se podrán añadir muchos más nombres en los próximos años. 
8. LADERO QUESADA, Miguel Ángel [F⿱ Academia de la Historia, 2009.

9. Sin duda el más antiguo de los aparatos regios, que siguió evolucionando ya en la Baja Edad Media. Para los orígenes plenomedievales: MARTÍN PRIETO, Pablo 瓶 “Invención y tradición en la cancillería de Alfonso VIII de Castilla (1158-1214)”. Espacio Tiempo y Forma. Serie III Historia Medieval 26 (2013), pp. 209-244; KLEINE, Marina [20 Lancillería real de Alfonso X: actores y prácticas en la producción documental. Sevilla: Universidad de Sevilla, 2015. Un ejemplo de participación en diplomacia: CAÑAS GÁLVEZ, Francisco de Paula [20 "La diplomacia castellana durante el Reinado de Juan II: la participación de los letrados de la cancillería real en las embajadas regias”. Anuario de Estudios Medievales 40-2 (2010), pp. 691-722.

10. GARRIGA ACOSTA, Carlos Antonio [50 La Audiencia y las chancillerías castellanas (1371-1525): historia política, régimen jurídico y práctica institucional, Madrid: Centro de Estudios Constitucionales, 1994; sobre su origen DÍAZ MARTíN, Luis Vicente [20 ${ }_{20}^{\circ} L$ os orígenes de la Audiencia Real castellana. Sevilla: Universidad de Sevilla, 1997.

11. Es clásico y básico el trabajo de DIOS, Salustiano de 媐 El Consejo Real de Castilla (1285-1522). Madrid: Centro de Estudios Constitucionales, 1982.

12. Sobre la burocracia regia véase: CAÑAS GÁLVEZ, Francisco de Paula 医 Burocracia y cancillería en la corte de Juan II de Castilla (1406-1454) estudio institucional y prosopográfico. Salamanca: Ediciones Universidad de Salamanca, 2012.

13. CAÑAS GÁLVEZ, Francisco de Paula 海 Burocracia ..., p. 184.

14. Una aproximación a esa variedad y su importancia en: ZALDÍVAR, Antonio [20 Language and Power in the Medieval Crown of Aragon: The Rise of Vernacular Writing and Codeswitching Strategies in the Thirteenth-Century Royal Chancery. Los Angeles: Universidad de California en Los Ángles, 2014. Tesis doctoral.

15. CAÑAS GÁLVEZ, Francisco de Paula 颔 Burocracia..., pp. 150-151.

16. GONZÁLEZ CRESPO, Esther 脱 “Organización de la cancillería castellana en la primera mitad del siglo XIV”. En la España Medieval 8 (1986), pp. 447-470, en concreto p. 449. La noticia la toma de Cortes de los antiguos reinos de León y Castilla. Madrid: Real Academia de la Historia, 1861, vol. 1, p. 203.

17. KLEINE, Marina 瞖 La cancillería real de Alfonso X. Actores y prácticas en la producción documental, Sevilla: Universidad de Sevilla, 2015, anexo prosopográfico, p. 336 y ss. En concreto tienen un destino diplomático las de 1255, 06, 15 (archivo de la Catedral de Toledo (en adelante ACT), I. 11.3.C.62, doc. 1); 1254, 04, 01 (RYMER, Thomas 熙 Foedera, conventiones, litterae, et cujuscunque generis acta publica, inter reges Angliae et alios quosvis imperatores, reges, pontifices, principes, vel communitates : ab ingressu Gulielmi I. in Angliam, A.D. 1066, ad nostra usque tempora habita aut tractata. Londres, 1816-1869, vol. I-1, p. 179); 1254, 04, 22 (RYMER, Thomas 媐 Foedera..., vol. I-1, pp. 180-181); 1255, 05, 05 (ACT, I.11.3.C.62 doc. 4); 1255, 05, 05 (ACT, I.11.3.C.62 doc. 2); y 1255, 06, 15 (ACT, I.11.3.C.62 doc. 1).

18. KLEINE, Marina 医 La cancillería..., apéndice prosopográfico, p. 522; Archivo de la Corona de Aragón (en adelante ACA), Cartas Reales, Jaime I, caja 1, nº 101, 101bis y 125.

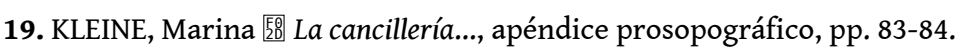

20. DÍAZ MARTÍN, Luis Vicente 䁂 Colección documental de Pedro I de Castilla (1350-1369). Salamanca: Junta de Castilla y León, 1999, vol. 3, doc. 749, p. 95. Agradezco a Francisco José Díaz Marcilla haberme facilitado esta noticia. También aparece mencionado como tal, ese mismo año, en el convenio de paz firmado entre Pedro I de Castilla y Pedro el Ceremonioso de Aragón: ACA, Cancillería, Reg. 557, ff. 142v-147r; publicado en FERRER I MALLOL, María Teresa 200 Entre la paz y la guerra. La Corona catalano-aragonesa y Castilla en la Baja Edad Media. Barcelona: CSIC, 2005, p. 555. 21. CAÑAS GÁLVEZ, Francisco de Paula [20 Colección diplomática de Santo Domingo el Real de Toledo. Documentos Reales I. 1249-1473. Madrid: Sílex ediciones, 2010, doc. 17, p. 52 y ss.

22. Archivo Histórico de la Nobleza (en adelante AHNob), Osuna, C. 3484, doc. 22, f. 2 r. 
23. GOÑI GAZTAMBIDE, José 㡠 “Los españoles en el Concilio de Constanza II”. Hispania Sacra 16 (1963), pp. 106-200, en concreto p. 197.

24. Véanse, sucintamente, en Villarroel González, Óscar, El rey y la Iglesia castellana. Relaciones de poder en época de Juan II. Madrid: Fundación Ramón Areces, 2011, pp. 607-608.

25. CAÑAS GÁLVEZ, Francisco de Paula 胼 Burocracia..., p. 311.

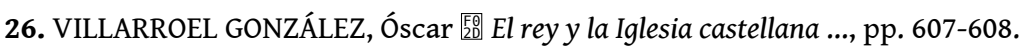

27. CAÑAS GÁLVEZ, Francisco de Paula 膯 Burocracia ..., p. 182.

28. CAÑAS GÁLVEZ, Francisco de Paula 潑 Burocracia ..., p. 196.

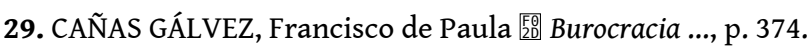

30. CAÑAS GÁLVEZ, Francisco de Paula 望 Burocracia ..., p. 289.

31. CAÑAS GÁLVEZ, Francisco de Paula 脭 Burocracia ..., p. 413.

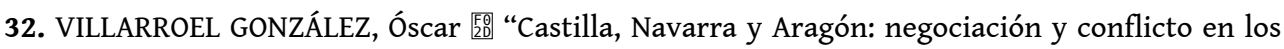
años 30 del siglo XV.” in NIETO SORIA, José Manuel; VILLARROEL GONZÁLEZ, Óscar (coords.) 医 Comunicación y conflicto en la cultura política peninsular (siglos XIII al XV). Madrid: Sílex, 2018, pp. 83-112.

33. SERRANO, Luciano, Los conversos don Pablo de Santamaría y Alonso de Cartagena. Obispos de Burgos, gobernantes, diplomáticos y escritores. Madrid: CSIC, 1942, p. 187.

34. CAÑAS GÁLVEZ, Francisco de Paula 澄 Burocracia ..., pp. 288-289.

35. GÓMEZ REDONDO, Fernando 溒 Historia de la prosa medieval castellana. III. Los orígenes del humanismo. El marco cultural de Enrique III y Juan II. Madrid: Cátedra, 2002, pp. 2541-2542.

36. STREET, Florence, "La vida de Juan de Mena". Bulletin Hispanique 55-2 (1953), pp. 154-155.

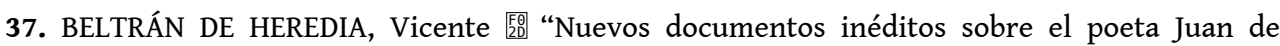
Mena". Salmanticensis 3-1 (1956), pp. 502-508, en concreto p. 505 y ss.

38. Sobre este personaje véase: CAÑAS GÁLVEZ, Francisco de Paula [⿰氵⿴囗大미 "Juan de Mena: secretario de latín y cronista del rey.” in MOYA GARCÍA, Cristina (ed.) 膯 Juan de Mena. De letrado a poeta. Woodbridge, 2015, pp. 11-22.

39. Archivo General de Simancas (en adelante AGS), Patronato Real, caj. 21, no 9, f. 20v.

40. VILLARROEL GONZÁLEZ, Óscar 海 “"Castilla y el Concilio de Siena (1423-1424): la embajada regia y su actuación”. En la España Medieval 30 (2007), pp. 131-172, en concreto p. 141.

41. AGS, Estado-Francia, K.1711, ff. $445 \mathrm{v}$.

42. Así lo presentó Luciano Serrano (Los conversos..., p. 126). La crónica de Juan II indica que envió a Alonso de Cartagena "e mandó que fuese con él un escribano de Cámara suyo que llamaban Joan Alfonso de Zamora" (GALÍNDEZ DE CARVAJAL, Lorenzo (comp.) 沮 Crónica del serenísimo príncipe don Juan, en Crónicas de los Reyes de Castilla. Madrid, 1877, en el volumen 69 de la Biblioteca de Autores Españoles, p. 411b). La indicación de cómo se le envió hace plausible que su misión fuese más como secretario que como embajador. En el prólogo a la traducción de Cicerón que hizo Cartagena a petición de Alonso de Zamora estando en Portugal, se presenta a éste último como secretario real (Biblioteca Nacional de España (en adelante BNE), ms. 7815, f. 5r. Y el mismo Cartagena presenta a ambos como embajadores (f. 6r).

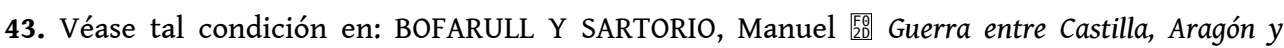
Navarra: compromiso para terminarla (año 1431). Barcelona: Colección de Documentos Inéditos del Archivo de la Corona de Aragón, 1869, p. 26. Sobre las negociaciones: VILLARROEL GONZÁLEZ, Óscar [20.60 “Castilla, Navarra y Aragón (...)”.... .

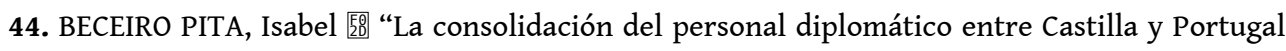
(1392-1455)." in GONZÁLEZ JIMÉNEZ, Manuel (ed.) Fo ${ }_{20}^{2} L a$ península ibérica en la era de los descubrimientos 1301-1492. Actas de las III jornadas hispano portuguesas de Historia Medieval. Sevilla, 1997, pp. 1735-1744, en concreto p. 1741-1742.

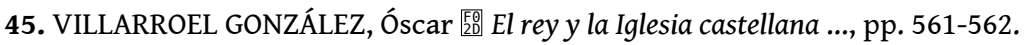

46. Véase por ejemplo: VILLARROEL GONZÁLEZ, Óscar [F⿱ castellana en el siglo XV" ... . 
47. VILLARROEL GONZÁLEZ, Óscar 㡠 “Eclesiásticos en la diplomacia castellana en el siglo XV” ..., pp. 793-801.

48. Véase: VILLARROEL GONZÁLEZ, Óscar [50⿱20.0 “Autoridad, legitimidad y honor en la diplomacia: los conflictos anglo-castellanos en los concilios del siglo XV". Espacio, Tiempo y Forma. Serie III Historia Medieval 29 (2016), pp. 777-813.

49. Véase al caso de Basilea: VILLARROEL GONZÁLEZ, Óscar 澄 “Autoridad, legitimidad y honor en la diplomacia (...)"..., p. 798.

50. Sobre la continuidad de este conflicto y su reflejo en las fuentes me remito a la obra citada en las dos notas anteriores.

51. VILLARROEL GONZÁLEZ, Óscar El El rey y el papa. Política y diplomacia en los albores del Renacimiento (el siglo XV en Castilla). Madrid: Sílex ediciones, 2009, pp. 93-94 y, especialmente, 128-130.

52. Sobre la labor diplomática del prelado y esta misión: VILLARROEL GONZÁLEZ, Óscar 医 "Alvaro Núñez de Isorna: un prelado y el poder". Edad Media. Revista de Historia 18 (2017), pp. 263-292.

53. Sobre el conflicto: VILLARROEL GONZÁLEZ, Óscar 期 “Autoridad, legitimidad y honor en la diplomacia (...)" ..., pp. 789-792.

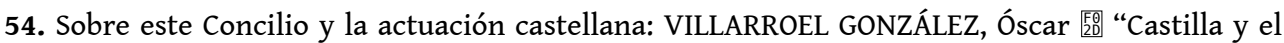
Concilio de Siena (1423-1424): la embajada regia y su actuación", ... .

55. El desarrollo del conflicto, con los discursos de ambas legaciones, en: VILLARROEL GONZÁLEZ, Óscar 覧 “Castilla y el Concilio de Siena (1423-1424): la embajada regia y su actuación” ..., pp. 162-168. El texto original donde se copiaron los discursos en: BRANDMÜLLER, Walter, Das Konzil von Pavia-Siena. Munster: Aschendorf, 1968-1974, vol. 2, pp. 303-432.

56. VILLARROEL GONZÁLEZ, Óscar 澄 “Autoridad, legitimidad y honor en la diplomacia (...)” ..., pp. 793-795.

57. El mejor análisis del conflicto se encuentra en: FERNÁNDEZ GALLARDO, L. F⿱ ${ }_{20}$ Alonso de Cartagena. Iglesia, política y cultura en la Castilla del siglo XV, Madrid: Universidad Complutense de Madrid, 1998, pp. 924-1004. Tesis doctoral. [Consultado el 12 junio 2020] Disponible en http:// eprints.ucm.es/2509/.

58. Ambos trabajos han sido editados y analizados en diversas ocasiones. Sobre la precedencia

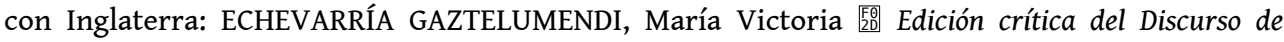
Alfonso de Cartagena "Propositio super altercatione praeminentia sedium inter oratores regum castellae et angliae in Concilio Basiliense", versiones en latín y castellano. Madrid: Universidad Complutense, Servicio de Reprografía, 1992. Es una edición difícil de localizar, sin embargo, de ahí que sea más utilizada la más antigua: CARTAGENA, Alfonso de [20 “Discurso sobre la precedencia del rey Católico sobre el de Inglaterra en el Concilio de Basilea." in PENNA, Mario (ed.) 医 Prosistas castellanos del siglo XV. Vol. I. Madrid: Atlas, 1959, pp. 205-233. Y sobre el conflicto con Portugal: GONZÁLEZ ROLÁN, T.; HERNÁNDEZ GONZÁLEZ, F.; SAQUERO SUÁREZ-SOMONTE, P. F⿱ ${ }_{20}^{0}$ Diplomacia y humanismo en el siglo XV Edición crítica, traducción y notas de las «Allegationes super conquesta Insularum Canariae contra portugalenses» de Alfonso de Cartagena. Madrid: UNED, Universidad Nacional de Educación a Distancia, 1994.

59. Sobre ambas cuestiones puede verse: FERNÁNDEZ GALLARDO, Luis [⿰氵⿴囗⿱一一⿻口卄- Alonso de Cartagena (1385-1456). Una biografía política en la Castilla del siglo XV. Valladolid: Junta de Castilla y León, 2002, pp. 133-160 (conflicto anglo-castellano), y 185-208 (luso-castellano). También ÁLVAREZ

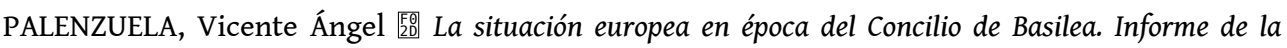
delegación del reino de Castilla. León: Centro de Estudios e Investigación San Isidoro, 1992, pp. 55-70 (conflicto anglo-castellano), y pp. 81-95 (luso-castellano).

60. Véase, por ejemplo, como eso ocurre en el transcurso de los conflictos anglocastellanos: VILLARROEL GONZÁLEZ, Óscar 医 “Autoridad, legitimidad y honor en la diplomacia (...)” ..., pp. 805-807. 
61. Se ha dicho de alguno, como Gonzálo de Santa María de Basilea (ÁLVAREZ PALENZUELA, Vicente Ángel 医 La situación..., p. 299; cfr. VILLARROEL GONZÁLEZ, Óscar 医 “Comunicar y negociar ...", p. 6).

62. A Roma se llevaron, por ejemplo, copia de las cartas que el rey había enviado a cardenales, así como al mismo arzobispo, también del cabildo al papa. También muestra el conocimiento del derecho canónico en lo tocante a las elecciones y quién puede y quién no reclamar. Todo ello, junto a otras piezas que se recogen en: AC Toledo, A-8. L.1. 1., también copias en BNE, ms. 13018, ff. $147 \mathrm{r}-181 \mathrm{r}$

63. Los mismos hispanos citan las actas y los ingleses les remiten a ellas en otra ocasión

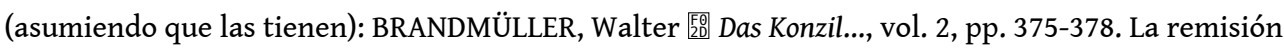
inglesa en pp. 410-412. Las obras las identifica el mismo Brandmüller: la historia eccelsiástica

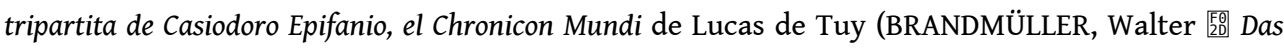
Konzil..., vol. 2, pp. 375).

64. Las cartas de Juan Martínez Contreras, por ejemplo, ACA, Cancillería Real, Cartas Reales, Alfonso el Magnánimo, 1698, 1699, 1705, 1710... (a los diputados de los reinos de Aragón y Navarra); 1519 (a los consejeros de Barcelona), 1601 (a los oficiales reales de Aragón). Sobre estas negociaciones véase: VILLARROEL GONZÁLEZ, Óscar [⿰氵⿴囗⿱一一⿻口卄乚 “Castilla, Navarra y Aragón (...)” ... .

65. VILLARROEL GONZÁLEZ, Óscar 医 “Castilla y el Concilio de Siena (1423-1424): la embajada regia y su actuación" ..., p. 169.

66. FERNÁNDEZ GALLARDO, Luis 医 Alonso de Cartagena ..., pp. 188-189.

67. FERNÁNDEZ GALLARDO, Luis 澄 Alonso de Cartagena ..., p. 192.

68. FERNÁNDEZ GALLARDO, Luis 澄 Alonso de Cartagena ..., pp. 196-197.

69. Conservadas todas ellas en ACT, A.8.L.1.1., con copia en BNE, ms. 13018, ff. 147-149v. Véase VILLARROEL GONZÁLEZ, Óscar 医 “Juan Martínez Contreras: el ascenso de un clérigo menor y el servicio regio.” in VILAR, Hermínia Vasconcelos; BRANCO, Maria João (eds.) [50 Ecclesiastics and political state building in the Iberian monarchies, 13th-15th centuries. Lisboa: Publicações do Cidehus, 2016 [Consultado el 17 octubre 2019]. Disponible en http://books.openedition.org/cidehus/1539, pp. 183-201, en concreto pp. 188-189.

70. Sobre la desinformación en el periodo medieval puede verse: VERDON, Jean désinformation au Moyen Âge. París: Perrin, 2010.

71. "Tamen debet laborari ne audiantur in publico consistorio, quia transire per linguas advocatorum in publico consistorio peius est quam transire per linguas diabolorum, qui propter pecunias iterum venderent papam et beatum Petrum si viveret, deponendum de papatu facerent, sed dato quod debuissent audiri quod audiantur solum coram cardinalibus commisariis uel coram papa et cardinalibus in secreto consistorio et non in publico", ACT, A.8. L.1. 1a, f. 6r. Obviamente al final del mismo se preocupa porque todo lo dicho no salga del secreto entre ambos enviados "ista quod persona scribens nullo modo detegatur", ibídem.

72. BRANDMÜLLER, Walter 膯 Das Konzil..., II, p. 252.

73. BRANDMÜLLER, Walter 医 Das Konzi ..., II, p. 314.

74. Veáse al respecto: VILLARROEL GONZÁLEZ. Óscar “Fo “Castilla y el Concilio de Siena (1423-1424): la embajada regia y su actuación” ..., p. 146 y ss.

75. VILLARROEL GONZÁLEZ, Óscar 脱 “Legitimidad, autoridad y conflicto...”, passim.

76. En la actualdidad estoy analizando su evolución y los frutos espero vean la luz pronto. Puede verse una somera descripción de la embajada y de las fuentes disponibles en: VILLARROEL

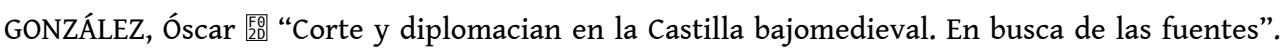
Mélanges de la Casa de Velázquez 45-2 (2015), pp. 105-124, en concreto pp. 115-118; también en VILLARROEL GONZÁLEZ, Óscar, “Castilla, Navarra y Aragón (...)”, ... .

77. ACA, Cancillería, Cartas reales, Alfonso IV [V], 1514.

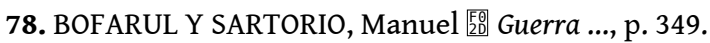

79. BOFARUL Y SATORIO, Manuel 医 Guerra ..., p. 184 y ss. 
80. Véase, por ejemplo, ACA, Cancillería, Cartas reales, Alfonso IV [V], desde 1514 hasta 2413. En ese lapso (todo de cartas relativas a la negociación) hay 44 cartas del prelado.

81. Por ejemplo en: ACA, Cancillería, Cartas Reales, Alfonso IV [V], 1552.

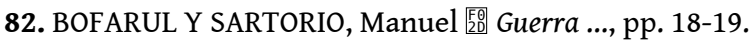

83. De hecho a lo largo del indicado legajo se conservan múltiples menciones a cosas que ya se han comunicado al rey, véase, por ejemplo, como en el margen del f. $67 \mathrm{r}$ se indica cómo se le había enviado ya un salvoconducto que se indica en el texto fue enviado al rey con más copias de escrituras el 3 de abril de ese mismo año: AGS, Estado-Francia, leg. K1711, f. 67r.

\section{RESÚMENES}

A lo largo del presente trabajo se analiza el desarrollo de la diplomacia regia y la contribución de algunos eclesiásticos, a lo largo de los siglos XIV y XV, en Castilla. A través del análisis de la aparición y desarrollo de algunos oficios de la corte con especial relevancia para la diplomacia, así como del análisis de algunos casos un tanto especiales de eclesiásticos al servicio regio en embajadas, se ofrecen algunas respuestas y otras preguntas para la futura investigación del funcionamiento y organización de la diplomacia castellana.

\section{ÍNDICE}

Keywords: In this paper we analyse the development of the royal diplomacy and the contributions of some ecclesiastics among the fourteenth and fifteenth century in Castile. Through the analysis of the birth and grown of the special diplomatic offices in the court a, and through some special cases of study of the role played by churchmen in the royal service, here offer some initial results and answers to some questions, and many questions for the future about the operation and development of the castillian diplomacy.

Palabras claves: Diplomacia, Monarquía, Castilla, Burocracia, Embajadores

\section{AUTOR}

\section{ÓSCAR VILLARROEL GONZÁLEZ}

Universidad Complutense de Madrid, Departamento de Historia Medieval 28040 Madrid, España. osvillar@ucm.es. https://orcid.org/0000-0001-6221-5689 